\title{
Gender and Health Care Utilisation in Pakistan
}

\author{
SYED MUBASHIR ALI
}

\begin{abstract}
This study is undertaken to test whether or not there exists gender bias in health care utilisation of sick children in Pakistan. Overall, the results are encouraging, as medical consultation has been sought for by a very high proportion ( 79 percent) of sick children. Moreover, there do not appear to be significant differences by gender in health care utilisation, be it curative or preventive. This is so in spite of the fact that many studies on various gender-related issues in Pakistan have generally shown significant gender bias in favour of male children. Thus one may conclude that parental altruism prevails at least in the provision of health care to sick children. However, the extent and magnitude of effect varies by geographical, socio-economic, and demographic characteristics of the mother.

In view of these findings, efforts should be made to minimise gender differentials among various categories of people so that children living in any circumstances may have equal opportunity of health care utilisation. This will be possible when health care facilities are easily accessible to all. The Lady Health Workers Programme of the Government of Pakistan is a major positive step in this regard. Under this programme, health care facilities are provided at people's door-step. The expansion of this programme will be extremely beneficial in helping parents to provide health care facilities to sick children, both male and female.
\end{abstract}

\section{INTRODUCTION}

Good health, a basic requirement, is essential for the survival and general well-being of all human beings. That is why access to health care, irrespective of caste, colour, or sex, is considered a fundamental human right. However, in poor countries this fundamental right may be accessible to a few, while a large majority may be denied it.

According to UNDP's Human Development Report (1996), Gender Equality Measure (GEM) for South Asia shows the lowest value (0.235) among all the regions of the world. Furthermore, as per Gender Development Index (GDI), Pakistan has been rated the poorest (0.179) among South Asian countries, where the average Index is 0.226 [MHDC (1999)].

Pakistan is a patriarchical society where generally females suffer discrimination in every walk of life. This gender discrimination, unfortunately, starts right from the day a baby-girl is born. The birth of a girl is unwelcome. As she grows, the scope of

Syed Mubashir Ali is Senior Research Demographer at the Pakistan Institute of Development Economics, Islamabad. 
this discrimination increases, be it nutritional needs or medical care, etc. Evidence from various national-level surveys shows a survival disadvantage for the girl-child particularly between 1-4 years of age [Ahmed et al. (1992); Pakistan Medical Research Council (1998); Cleland et al. (1998)].

In developed countries, where women live much longer than their male counterparts, the sex ratio is also in favour of females, whereas the sex ratio in Pakistan is the opposite of that finding, i.e., 108 males to 100 females [Pakistan (1998)]. It is often argued that differential use of curative health services is the main mechanism leading to greater survival of boys than girls [Booth and Verma (1992)]. The adverse sex ratio for the females could be due to excess mortality of girls owing to gender discrimination. In neighbouring India, where traditions and social norms are similar to those in Pakistan, Gupta (1987) indicates that there might be four times as many excess deaths of female children, which occur after rather than before birth or as unreported infanticides.

Keeping in view these empirical observations, we wish to investigate in this study whether girls are denied health care during illness, and also whether parents have any bias against girls in providing them general medical care and immunisation against the six main deadly but preventable diseases. We also investigate the factors that impede a girl's health care utilisation.

\section{DATA AND METHODOLOGY}

The analysis for this study is based on the data of the 1995-96 Pakistan Integrated Household Survey (PIHS), conducted round the year in four quarters. The sample size of the survey was 12800 households, which are representative of the national, provincial, and urban-rural levels. The selection of this data set was made on the grounds that it provides rich data for this kind of study.

The analysis is based on simple cross-tabulation and multivariate technique. The cross-tabulation is used to show unadjusted geographical, socio-cultural, economic, and demographic differential of health care utilisation of male and female children. From among the multivariate techniques, the technique of logistic regression is applied to test the net influence of geographical, socio-cultural, economic, and demographic variables on (1) the health care utilisation of children of less than 10 years of age who are sick and (2) the immunisation status of children of 5 or less years of age. The health care utilisation variable in this study refers to the provision of health care to sick children by either qualified health care practitioners (doctors, nurses, health care workers) or traditional health practitioners like a herbalist/ hakim/homoeopath, etc.

The dependent variables in the analysis were defined as dichotomous variables where value ' 1 ' is assigned to all those children for whom consultation was sought and also to those who were ever immunised. Otherwise a value of ' 0 ' is given. Among the predictor variables, geographical variables were urban-rural and 
provincial residence. Mother's education and family type are taken as socio-cultural variables respectively. The first equation consists of these variables only and is termed as control equation. In the second step (Model-2), mother's employment and monthly household expenditure were added to the first equation. Model-3 consists of the demographic variables in addition to the variables in Model-2.

The logistic regression is mathematically defined as:

$$
\ln \frac{p}{(1-p)}=a+\sum_{i=1}^{k} b_{j} X_{i}
$$

Where $p$ is the probability of a child's having utilised health care facility or being immunised; $a$ is the intercept; $b_{j}$ are estimated regression coefficients and $x_{i}$ are the background characteristics.

The analysis is carried out on the total sample as well as on male and female children separately. The variables in all these equations are the same, except that in the equation based on the total sample an additional variable on the sex of the children was added. This variable was added in order to estimate the net effect of gender on health care utilisation, be it curative or preventive.

\section{THEORETICAL CONTEXT}

Traditionally sons are valued more than daughters in the Pakistani society. It is so because sons are considered to be beneficial to parents not only because they are potential contributors to the family income but also because they provide financial security to parents in their old age. In Pakistan, a mother as the primary caretaker of children not only takes pride in bearing sons but also makes extra effort to maintain their health in the best state, as the survival of sons is considered to be a source of strength for herself. Moreover, in this patriarchical society, the survival of sons also embodies the desire to carry forward the family name.

It has also been noticed that in the intra-household distribution of resources, male members are given preferential treatment, whether in the distribution of food, medical treatment, or education. Traditionally, male members of a family are not only served first but also with the best of food available in a household. The evidence from the National Health Survey of Pakistan also shows that the proportion of severely malnourished children is higher for girls than for boys [Pakistan Medical Research Council (1998)]. This situation becomes more pronounced among poor families under financial stress. Data from Islamabad Children's Hospital show that the number of girls brought there for health care between January 1989 and September 1990 was nearly one-quarter lower than that for boys [cited in Mahmood and Mahmood (1995)]. A possible explanation is that the daughters are not considered as important. Normally a daughter provides no financial support to her parents; instead from the day she is born she is considered a liability and a burden, as cultural norms require a large dowry at the time of her marriage. 
However, isolated studies based on small data sets contradict the above findings [Hafeez (2001); Williamson and Boehmer (1997)]. In order to test the prevalence of gender bias in the health utilisation of children, we hypothesise that sons, when sick, may be better attended to and provided medical care. This is because the survival of sons is considered to be more important than that of daughters. Likewise, preventive health care, measured here in terms of immunisation status, is also provided more to sons than to daughters.

\section{GEOGRAPHICAL, SOCIO-CULTURAL, ECONOMIC, AND DEMOGRAPHIC DIFFERENTIALS OF HEALTH CARE UTILISATION}

In the socio-economic context, Pakistan is a poor country. Over one-third of its population is below or at poverty line [Qureshi and Arif (1999)], the majority is illiterate, tap-water is available to one-fourth of the population, and nearly half of all households in Pakistan do not have a toilet [Pakistan (1997)]. Such a situation leads to disease and misery in society. Unfortunately, because of gender bias in favour of male members, females in this society are affected the most. However, the extent of 'biasedness' varies between various groups of population.

Table 1 shows that the incidence of sickness is the highest among children under 1 year of age and thereafter the incidence decreases with the increase in age. The incidence of sickness is 6 times more among infants as compared to children in age group 6-9 years. This pattern is in line with the fact that at very young ages children have a low resistance power and immunity against diseases, and thus they catch infections easily.

The biological advantage of females is reflected in the fact that relatively fewer female children were reported to be sick as compared to male children. Such differentials are more conspicuous among children of 1-5 years of age. However, the possibility of a reporting bias can not be ruled out. On the other hand, the incidence of immunisation is somewhat higher for the male than for female children. In the age group of less than 1 and 3 to 5 years of age, the incidence of immunisation was higher for female children.

Table 1

Percentage Distribution of Sick and Immunised Children According to Their Age

\begin{tabular}{|c|c|c|c|c|c|c|}
\hline \multirow[b]{2}{*}{ Age (in Years) } & \multicolumn{3}{|c|}{ Sick Children } & \multicolumn{3}{|c|}{ Immunised Children } \\
\hline & Male & Female & All & Male & Female & All \\
\hline$<1$ & 30.8 & 29.2 & 30.1 & 59.1 & 66.3 & 62.2 \\
\hline $1-2$ & 30.6 & 27.3 & 28.8 & 87.4 & 79.5 & 83.8 \\
\hline $3-5$ & 13.2 & 10.1 & 11.7 & 82.7 & 85.1 & 83.8 \\
\hline $6-9$ & 4.8 & 4.7 & 4.8 & - & - & - \\
\hline All & 13.2 & 12.0 & 12.6 & 81.3 & 80.6 & 81.0 \\
\hline
\end{tabular}


Table 2 shows the proportion of "sick children for whom medical consultation was sought" and "children's immunisation status" by geographical, socio-economic,

Table 2

Percentage Distribution of Sick Children for Whom Medical Consultation Was Sought According to Age and Other Socio-economic Characteristics

\begin{tabular}{|c|c|c|c|c|c|c|}
\hline \multirow[b]{2}{*}{ Age } & \multicolumn{3}{|c|}{ Health Care Utilisation } & \multicolumn{3}{|c|}{ Immunisation Status } \\
\hline & $\overline{\text { Male }}$ & Female & Total & Male & Female & Total \\
\hline$<1$ & 84.9 & 83.6 & 84.3 & 59.1 & 66.3 & 62.2 \\
\hline $1-2$ & 76.9 & 80.2 & 78.5 & 87.4 & 79.5 & 83.8 \\
\hline $3-5$ & 80.8 & 80.3 & 80.6 & 82.7 & 85.1 & 83.8 \\
\hline $6-9$ & 77.5 & 73.7 & 75.9 & - & - & - \\
\hline \multicolumn{7}{|l|}{ Region of Residence } \\
\hline Urban & 82.4 & 85.2 & 83.8 & 84.6 & 85.9 & 85.3 \\
\hline Rural & 77.7 & 75.1 & 76.5 & 80.0 & 78.4 & 79.3 \\
\hline \multicolumn{7}{|l|}{ Provinces } \\
\hline Punjab & 84.5 & 84.4 & 84.5 & 82.4 & 83.4 & 82.9 \\
\hline Sindh & 80.9 & 83.1 & 81.9 & 84.9 & 80.9 & 83.0 \\
\hline NWFP & 64.8 & 63.8 & 64.3 & 76.3 & 73.8 & 75.2 \\
\hline Balochistan & 43.4 & 36.8 & 40.5 & 67.6 & 69.4 & 68.4 \\
\hline \multicolumn{7}{|l|}{ Mother's Education } \\
\hline No Education & 77.5 & 77.4 & 77.5 & 79.4 & 78.1 & 78.8 \\
\hline Primary or Less & 81.6 & 77.7 & 79.8 & 86.6 & 86.6 & 86.6 \\
\hline Secondary or More & 89.3 & 87.9 & 88.7 & 93.3 & 91.8 & 92.5 \\
\hline \multicolumn{7}{|l|}{ Family Type } \\
\hline Nuclear & 78.6 & 77.7 & 78.2 & 81.8 & 78.5 & 80.3 \\
\hline Joint & 79.7 & 79.4 & 79.6 & 80.5 & 83.3 & 81.8 \\
\hline \multicolumn{7}{|l|}{ Mother's Employment } \\
\hline Working & 80.4 & 77.2 & 78.9 & 76.8 & 77.4 & 77.1 \\
\hline Not Working & 79.3 & 78.9 & 79.1 & 82.9 & 81.4 & 82.2 \\
\hline \multicolumn{7}{|c|}{ Monthly H.H. Expenditure } \\
\hline$<=2000$ Rupees & 83.7 & 80.1 & 82.2 & 75.5 & 77.3 & 76.3 \\
\hline $2001-4000$ & 78.1 & 77.5 & 77.8 & 83.3 & 80.2 & 81.8 \\
\hline $4001-6000$ & 78.3 & 82.0 & 80.2 & 82.1 & 83.9 & 82.9 \\
\hline $6001+$ & 71.1 & 74.0 & 72.7 & 84.5 & 86.9 & 85.7 \\
\hline \multicolumn{7}{|c|}{ Number of Living Children } \\
\hline$\leq 2$ & 76.3 & 82.2 & 79.2 & 81.4 & 85.1 & 83.1 \\
\hline $3-4$ & 83.3 & 80.3 & 81.8 & 88.4 & 81.8 & 85.0 \\
\hline $5-6$ & 79.5 & 73.5 & 76.8 & 77.5 & 77.8 & 77.6 \\
\hline $7+$ & 77.3 & 75.7 & 76.7 & 76.9 & 74.5 & 75.9 \\
\hline \multicolumn{7}{|l|}{ Number of Dead Sons } \\
\hline 0 & 81.0 & 81.0 & 81.0 & 83.3 & 82.4 & 82.9 \\
\hline 1 & 77.7 & 73.7 & 75.9 & 75.3 & 74.7 & 75.0 \\
\hline 2 & 62.8 & 69.1 & 66.1 & 76.0 & 82.0 & 79.1 \\
\hline $3+$ & 51.7 & 66.7 & 60.1 & 76.6 & 73.1 & 75.0 \\
\hline All & 79.0 & 78.4 & 78.7 & 81.3 & 80.6 & 81.0 \\
\hline
\end{tabular}


and demographic characteristic of their mothers. As is evident from the table, medical consultation was sought for about four out of every five sick children. By any standard, this is a very high proportion. The data of the National Health Survey of Pakistan show that Pakistanis in the age group of 15-44 years visit the health care providers 5.6 times annually. [Pakistan Medical Research Council (1998)]. This statistics compares favourably with the annual visits to health providers in the Unites States (5 visits annually). As such, there appears almost no gender differential in seeking medical consultation.

On the whole, maximum medical care is provided to children under age 1 but no pattern appears by age groups. However, some differentials between the male and female children by age groups are observed in the age groups 1-2 years and 6-9 years. The urban-rural residence does show some differentials as the urbanites are more careful ( 83.8 percent) about the well-being of their sick children as compared to the ones living in rural areas (76.5 percent). In Pakistan, health facilities are concentrated in urban areas, and because of easy access, people tend to take their children to these facilities more often when need arises. Whereas in urban areas female children are more likely to be provided with medical consultation, in rural areas it is totally the opposite. The proportion of immunised children also shows the same pattern.

The more developed the province, the better the health facilities, and so are the people more likely to seek medical consultation for their sick children. For example, over two times more health facilities were availed of by sick children in the province of Punjab than in the province of Balochistan. The province of Sindh does not lag behind Punjab much. Some male-female differentials are found in the province of Balochistan, where only male rather than female children are more likely to be provided with health care. The proportion of immunised children is the highest in the province of Sindh, followed by nearly the same level in the province of Punjab, while it is the lowest in the province of Balochistan.

As the majority of mothers do not enter the labour market and are around the house, they are more available to their children. As a result, they are the first providers of health care when their children are sick. An educated mother is generally more responsible and a better provider of health care when her child is in need of such care. By acquiring education, women are also exposed to the outside world. This brings a positive change to their perspectives and attitudes to children's health care.

Gender differentials in health care utilisation more likely occur among somewhat educated mothers, i.e., the ones with primary or less education, suggesting that these mothers care more for boys when they are sick. A mother's education is also positively related to the immunisation status of children. However, gender differentials are not pronounced among various categories of mother's education. 
Living in nuclear or joint families also influences health-seeking behaviour. It is hypothesised that in a joint family, it is the in-laws or the elders who take most of the decisions in the household and feel responsible for carrying out day-to-day chores. Moreover, as there are more adults in a family, provision of health care becomes easier when need be.

The results of Table 2 show that there is little noticeable health care utilisation differential by family type. Likewise, such differentials by gender are also more or less non-existent in both the living set-ups. Interestingly, among immunised children, the girls in comparison to boys are less likely to be immunised in a nuclear set-up than in a joint family set-up, implying a relatively higher value of sons in nuclear setups.

Mother's employment status is another variable, which should bring differentials in the proportion of children for whom curative or preventive health care utilisation was sought. Normally, a Pakistani working woman, besides her gainful job, is also responsible for household chores and welfare of husband and children. In carrying out these duties, she becomes overburdened and in the process children are the ones who suffer the most. The irony is that although she is working for the welfare of her family and children, it is the children whose welfare is most affected adversely.

However, the above argument does not hold true so far as the provision of curative care is concerned, as there hardly appears any such differentials between the working and the non-working women. Nevertheless, some gender differentials in the provision of health care to sick children are found among working women only. As expected, the proportion of immunised children of non-working women was higher than those of working women. However, the differences by gender in the immunisation status of children were negligible.

In Pakistan, people prefer more children as there is a socio-cultural, economic, and emotional value attached to them. When the first child is born, he or she is cared for well. This is because the first child is considered to be a good omen, especially for the mother. Nevertheless, as the number of children increases, the economic law of diminishing return operates and hence the socio-cultural, economic, and emotional value attached to the children decreases. Thus not much care is offered to children in general, and to older children in particular.

Table 2 indicates that maximum medical care was provided to those sick children whose parents have 3-4 living children, and the least to those sick children whose parents have $7+$ living children. Interestingly, among various groups of living children, parents with 5-6 children showed the maximum gender differentials, i.e., whereas 79.5 percentage of male sick children were provided medical attention, the corresponding proportion for female sick children was 73.5 percent.

As is true in many societies in the world, sons are valued in Pakistan as well due to various socio-economic and familial reasons. It is hypothesised that in 
families where more deaths of sons have been suffered, better health care will be provided for the remaining children in general, and to sons in particular, so as to avoid more losses.

Contrary to the above-stated hypothesis, a clear inverse relationship is evident between the number of dead sons and health care utilisation for sick children. For example, in cases where no death of sons is reported, 81 percent of the sick children were provided health care. On the other hand, where the loss is 3 or more sons, only 60 percent have been given health care. Among the sample of male children, this inverse relationship becomes more conspicuous as the difference here increases to 29 percentage points. The inverse relationship between the number of dead sons and the health care utilisation for sick children is likely to be related to the poor socio-economic status of families. Nevertheless, a clearer picture of this relationship may emerge in the following multivariate analysis.

Although the economic status of a household is indicated by its monthly expenditure and people spending more are expected to utilise health care facilities for their sick children, yet the results in Table 2 show a reverse pattern. That is, the households incurring $<=$ Rs 2000 monthly expenditure were more likely to have been using health care facilities for their sick children. On the other hand, the least utilisation was observed in the highest monthly expenditure group. A comparison of health care utilisation among male and female sick children shows a mixed pattern, i.e., whereas households incurring an expenditure $<=$ Rs 2000 per month showed the highest proportion of health care utilisation for male children. The highest utilisation of health care facilities for female children was observed among those households which were incurring a monthly expenditure of Rs 4001-6000. On the other hand, a positive relationship was evident between the immunisation status of children and the monthly household expenditure.

\section{THE MULTIVARIATE ANALYSIS RESULTS}

The regression coefficients along with their respective odd ratios are presented in Tables 3, 4, and 5. Table 3 pertains to total sample whereas Tables 4 and 5 are bifurcated by male and female data respectively. This is done in order to test if the effect of predictor variables on the dependent variables is different in the two settings based on gender. Each of these tables consists of 6 equations. In Table 3, the first three equations explain the effect of predictor variables on health care utilisation, and the last three on the immunisation status of children. Tables 4 and 5 present a comparative picture of the analysis by gender on the health care utilisation and immunisation status of children respectively. 
Table 3

Logistic Regression Coefficients and Effects (Odd Ratios) of Selected Predictor Variables on Health Utilisation and Immunisation Status of Children

\begin{tabular}{|c|c|c|c|c|c|c|c|c|c|c|c|c|}
\hline \multirow[b]{3}{*}{$\begin{array}{l}\text { Predictor } \\
\text { Variables }\end{array}$} & \multicolumn{6}{|c|}{ (a) Health Care Utilisation of All Children Less than 10 Years of Age } & \multicolumn{6}{|c|}{ (b) Immunisation Status of All Children 5 or Less Years of Age } \\
\hline & \multicolumn{2}{|c|}{ Model-1 } & \multicolumn{2}{|c|}{ Model-2 } & \multicolumn{2}{|c|}{ Model-3 } & \multicolumn{2}{|c|}{ Model-1 } & \multicolumn{2}{|c|}{ Model-2 } & \multicolumn{2}{|c|}{ Model-3 } \\
\hline & $\begin{array}{l}\text { Co- } \\
\text { efficients }\end{array}$ & $\begin{array}{c}\text { Odd } \\
\text { Ratios }\end{array}$ & $\begin{array}{c}\text { Co- } \\
\text { efficients }\end{array}$ & $\begin{array}{c}\text { Odd } \\
\text { Ratios }\end{array}$ & $\begin{array}{c}\text { Co- } \\
\text { efficients }\end{array}$ & $\begin{array}{c}\text { Odd } \\
\text { Ratios }\end{array}$ & $\begin{array}{c}\text { Co- } \\
\text { efficients }\end{array}$ & $\begin{array}{c}\text { Odd } \\
\text { Ratios }\end{array}$ & $\begin{array}{c}\text { Co- } \\
\text { efficients }\end{array}$ & $\begin{array}{c}\text { Odd } \\
\text { Ratios }\end{array}$ & $\begin{array}{c}\text { Co- } \\
\text { efficients }\end{array}$ & Odd Ratios \\
\hline Constant & 0.6656 & & .6512 & & .7900 & & .4739 & & .3531 & & .4452 & \\
\hline Age & .0022 & 1.0022 & .0060 & 1.0060 & .0128 & 1.0129 & $.1226^{* * *}$ & 1.1304 & $.1237^{* * *}$ & 1.1317 & $.1296^{* * *}$ & 1.1384 \\
\hline \multicolumn{13}{|l|}{ Gender } \\
\hline \multicolumn{13}{|l|}{ Girls $^{\mathrm{a}}$} \\
\hline Boys & -.0001 & .9999 & .0065 & 1.0065 & .0168 & 1.0170 & -.0034 & .9966 & .0132 & 1.0133 & .0266 & 1.0269 \\
\hline \multicolumn{13}{|l|}{ Residence } \\
\hline \multicolumn{13}{|l|}{ Rural $^{\mathrm{a}}$} \\
\hline Urban & $.3734 * * *$ & 1.4526 & $.3060^{* *}$ & 1.3580 & $.3167^{* *}$ & 1.3725 & $.3393 * *$ & 1.4040 & $.2625^{*}$ & 1.3002 & $.2750 *$ & 1.3166 \\
\hline \multicolumn{13}{|l|}{ Province } \\
\hline \multicolumn{13}{|c|}{ Balochistan $^{\mathrm{a}}$} \\
\hline Punjab & $1.1226^{* * *}$ & 3.0728 & $1.1246^{* * *}$ & 3.0789 & $1.1873^{* * *}$ & 3.2781 & $.5185^{* *}$ & 1.6795 & $.6110^{* *}$ & 1.8422 & $.7041 * *$ & 1.8266 \\
\hline Sindh & $1.0396^{* * *}$ & 2.8282 & $1.0628^{* * *}$ & 2.8945 & $1.1466^{* * *}$ & 3.1476 & .3758 & 1.4561 & .4760 & 1.6096 & $.6025^{*}$ & 1.8266 \\
\hline NWFP & $.6220 * * *$ & 1.8627 & $.5567 * * *$ & 1.7448 & $.6932 * * *$ & 2.0002 & .3934 & 1.4820 & .2835 & 1.3277 & .4617 & 1.5868 \\
\hline \multicolumn{13}{|c|}{ Mother's Education } \\
\hline \multicolumn{13}{|c|}{ Uneducated $^{\mathrm{a}}$} \\
\hline $\begin{array}{l}\text { Primary or } \\
\text { Less }\end{array}$ & .0192 & 1.0193 & -.0147 & 0.9854 & -.0752 & .9276 & $.7031^{* * *}$ & 2.0201 & $.6224 * *$ & 1.8633 & $.5645^{* *}$ & 1.7585 \\
\hline $\begin{array}{l}\text { Secondary } \\
\text { More }\end{array}$ & .0349 & 1.0355 & .0145 & 1.0146 & -.1058 & .8996 & $1.0042 * * *$ & 2.7297 & $.9159^{* * *}$ & 2.4990 & $.7975^{* *}$ & 2.2200 \\
\hline \multicolumn{13}{|l|}{ Family Type } \\
\hline \multicolumn{13}{|l|}{ Joint $^{\mathrm{a}}$} \\
\hline Nuclear & $-.3005^{* * *}$ & .7404 & $-.2425 * *$ & 0.7845 & $-.2829 * *$ & .7536 & -.0904 & .9136 & -.0235 & .9768 & -.0562 & .9454 \\
\hline
\end{tabular}


Continued-

Table 3-(Continued)

\begin{tabular}{|c|c|c|c|c|c|c|c|c|c|c|c|c|}
\hline \multirow[b]{3}{*}{$\begin{array}{l}\text { Predictor } \\
\text { Variables }\end{array}$} & \multicolumn{6}{|c|}{ (a) Health Care Utilisation of All Children Less than 10 Years of Age } & \multicolumn{6}{|c|}{ (b) Immunisation Status of All Children 5 or Less Years of Age } \\
\hline & \multicolumn{2}{|c|}{ Model-1 } & \multicolumn{2}{|c|}{ Model-2 } & \multicolumn{2}{|c|}{ Model-3 } & \multicolumn{2}{|c|}{ Model-1 } & \multicolumn{2}{|c|}{ Model-2 } & \multicolumn{2}{|c|}{ Model-3 } \\
\hline & $\begin{array}{c}\text { Co- } \\
\text { efficients }\end{array}$ & $\begin{array}{c}\text { Odd } \\
\text { Ratios }\end{array}$ & $\begin{array}{c}\text { Co- } \\
\text { efficients }\end{array}$ & $\begin{array}{c}\text { Odd } \\
\text { Ratios }\end{array}$ & $\begin{array}{c}\text { Co- } \\
\text { efficients }\end{array}$ & $\begin{array}{c}\text { Odd } \\
\text { Ratios }\end{array}$ & $\begin{array}{c}\text { Co- } \\
\text { efficients }\end{array}$ & $\begin{array}{c}\text { Odd } \\
\text { Ratios }\end{array}$ & $\begin{array}{c}\text { Co- } \\
\text { efficients }\end{array}$ & $\begin{array}{c}\text { Odd } \\
\text { Ratios }\end{array}$ & $\begin{array}{c}\text { Co- } \\
\text { efficients }\end{array}$ & $\begin{array}{c}\text { Odd } \\
\text { Ratios }\end{array}$ \\
\hline \multicolumn{13}{|c|}{ Mother's Employment } \\
\hline \multicolumn{13}{|c|}{ Not Working ${ }^{\mathrm{a}}$} \\
\hline Working & & & -.1998 & .8189 & -.1750 & .8395 & & & $-.3845^{* *}$ & 6810 & $-.3597 * *$ & 6979 \\
\hline Montly Household & & & & & & & & & & & & \\
\hline Expenditure & & & . 0000 & 1.0000 & .0001 & 1.0001 & & & $-.0001 *$ & 1.0001 & $.0002 * *$ & 1.0002 \\
\hline $\begin{array}{l}\text { Number of Living } \\
\text { Children }\end{array}$ & & & & & $-.0381 * *$ & .9626 & & & & & $-.0504 * *$ & .9509 \\
\hline $\begin{array}{l}\text { Number of Sons } \\
\text { who have Died }\end{array}$ & & & & & $-.1481^{* *}$ & .8623 & & & & & -.0585 & 9432 \\
\hline -2 Log Likelihood & 3400.22 & & 3149.46 & & 3149.46 & & 2152.32 & & -.2056 .28 & & 2056.28 & \\
\hline Model Chi & & & & & & & & & & & & \\
\hline Squared & 92.092(9) & & $85.25(11)$ & & 101.11(13) & & 71.87(9) & & $82.85(11)$ & & 92.42(13) & \\
\hline Use Correctly & & & & & & & & & & & & \\
\hline Predicted & 81.62 & & 81.59 & & 81.59 & & 79.80 & & 79.88 & & 79.83 & \\
\hline Total $\mathrm{N}$ & 3563 & & 3298 & & 3298 & & 2139 & & 2048 & & 2048 & \\
\hline
\end{tabular}

Source: Original data file of PIHS 1995-96.

*Significant at .05 level.

**Significant at .01 leve

**Significant at 001 level.

${ }^{a}$ Reference category. 
Table 4

Logistic Regression Coefficients and Effects (Odd Ratios) of Selected Predictor Variables on Health Care Utilisation

\begin{tabular}{|c|c|c|c|c|c|c|c|c|c|c|c|c|}
\hline \multirow[b]{3}{*}{$\begin{array}{l}\text { Predictor } \\
\text { Variables }\end{array}$} & \multicolumn{6}{|c|}{ (a) Male Children Less than 10 Years of Age } & \multicolumn{6}{|c|}{ (b) Female Children Less than 10 Years of Age } \\
\hline & \multicolumn{2}{|c|}{ Model-1 } & \multicolumn{2}{|c|}{ Model-2 } & \multicolumn{2}{|c|}{ Model-3 } & \multicolumn{2}{|c|}{ Model-1 } & \multicolumn{2}{|c|}{ Model-2 } & \multicolumn{2}{|c|}{ Model-3 } \\
\hline & $\begin{array}{c}\text { Co- } \\
\text { efficients }\end{array}$ & $\begin{array}{c}\text { Odd } \\
\text { Ratios }\end{array}$ & $\begin{array}{c}\text { Co- } \\
\text { efficients }\end{array}$ & $\begin{array}{c}\text { Odd } \\
\text { Ratios }\end{array}$ & $\begin{array}{c}\text { Co- } \\
\text { efficients }\end{array}$ & $\begin{array}{c}\text { Odd } \\
\text { Ratios }\end{array}$ & $\begin{array}{c}\text { Co- } \\
\text { efficients }\end{array}$ & $\begin{array}{c}\text { Odd } \\
\text { Ratios }\end{array}$ & $\begin{array}{c}\text { Co- } \\
\text { efficients }\end{array}$ & $\begin{array}{c}\text { Odd } \\
\text { Ratios }\end{array}$ & $\begin{array}{c}\text { Co- } \\
\text { efficients }\end{array}$ & $\begin{array}{c}\text { Odd } \\
\text { Ratios }\end{array}$ \\
\hline Constant & 6944 & & .7389 & & .8433 & & .6421 & & .5408 & & .7314 & \\
\hline Age & .0123 & 1.0123 & .0143 & 1.0144 & .0194 & 1.0196 & -.0115 & .9885 & -.0079 & .9921 & -.0001 & .9999 \\
\hline \multicolumn{13}{|l|}{ Residence } \\
\hline \multicolumn{13}{|l|}{ Rural $^{\mathrm{a}}$} \\
\hline Urban & .2545 & 1.2898 & .2495 & 1.2833 & .2648 & 1.3032 & $.5138^{* *}$ & 1.6717 & $.3715^{* *}$ & 1.4499 & $.3729 * *$ & 1.4513 \\
\hline \multicolumn{13}{|l|}{ Province } \\
\hline \multicolumn{13}{|l|}{ Balochistan $^{\mathrm{a}}$} \\
\hline Punjab & $.9945^{* * *}$ & 2.7034 & $.9678^{* * *}$ & 2.6321 & $1.0585^{* * *}$ & 2.8821 & $1.2806 * * *$ & 3.5990 & $1.3370^{* * *}$ & 3.8076 & $1.3806^{* * *}$ & 3.9774 \\
\hline Sindh & $.9126^{* * *}$ & 2.4909 & $.8860 * * *$ & 2.4254 & $.9996 * * *$ & 2.7171 & $1.1923 * * *$ & 3.2946 & $1.2905^{* *}$ & 3.6346 & $1.3389^{* * *}$ & 3.8147 \\
\hline NWFP & $.6324 * *$ & 1.8821 & $.5625^{* *}$ & 1.7550 & $.7349 * *$ & 2.0853 & $.6230 * *$ & 1.8646 & $.5735^{*}$ & 1.7744 & $.6743 * *$ & 1.9627 \\
\hline \multicolumn{13}{|l|}{ Mother's Education } \\
\hline \multicolumn{13}{|l|}{ Uneducated $^{\mathrm{a}}$} \\
\hline Primary or Less & .0691 & 1.0715 & .0416 & 1.0425 & -.0055 & .9945 & -.0194 & .9807 & -.0650 & .9371 & -.1341 & .8745 \\
\hline Secondary or More & .1019 & 1.1073 & .0823 & 1.0858 & -.0253 & .9750 & -.0423 & .9586 & -.0530 & .9484 & -.1888 & .8280 \\
\hline \multicolumn{13}{|l|}{ Family Type } \\
\hline \multicolumn{13}{|l|}{ Joint $\mathrm{a}^{\mathrm{a}}$} \\
\hline Nuclear & $-.2602 *$ & .7709 & -.2201 & .8025 & -.2492 & .7794 & $-.3552 * *$ & .7010 & -.2617 & .7697 & -.3080 & .7349 \\
\hline
\end{tabular}


Table 4-(Continued)

\begin{tabular}{|c|c|c|c|c|c|c|c|c|c|c|c|c|}
\hline \multirow[b]{3}{*}{$\begin{array}{l}\text { Predictor } \\
\text { Variables }\end{array}$} & \multicolumn{6}{|c|}{ (a) Male Children Less than 10 Years of Age } & \multicolumn{6}{|c|}{ (b) Female Children Less than 10 Years of Age } \\
\hline & \multicolumn{2}{|c|}{ Model-1 } & \multicolumn{2}{|c|}{ Model-2 } & \multicolumn{2}{|c|}{ Model-3 } & \multicolumn{2}{|c|}{ Model-1 } & \multicolumn{2}{|c|}{ Model-2 } & \multicolumn{2}{|c|}{ Model-3 } \\
\hline & $\begin{array}{c}\text { Co- } \\
\text { efficients }\end{array}$ & $\begin{array}{c}\text { Odd } \\
\text { Ratios }\end{array}$ & $\begin{array}{c}\text { Co- } \\
\text { efficients }\end{array}$ & $\begin{array}{c}\text { Odd } \\
\text { Ratios }\end{array}$ & $\begin{array}{c}\text { Co- } \\
\text { efficients }\end{array}$ & $\begin{array}{c}\text { Odd } \\
\text { Ratios }\end{array}$ & $\begin{array}{c}\text { Co- } \\
\text { efficients }\end{array}$ & $\begin{array}{l}\text { Odd } \\
\text { Ratios }\end{array}$ & $\begin{array}{c}\text { Co- } \\
\text { efficients }\end{array}$ & $\begin{array}{c}\text { Odd } \\
\text { Ratios }\end{array}$ & $\begin{array}{c}\text { Co- } \\
\text { efficients }\end{array}$ & $\begin{array}{c}\text { Odd } \\
\text { Ratios }\end{array}$ \\
\hline \multicolumn{13}{|c|}{ Mother's Employment } \\
\hline \multicolumn{13}{|c|}{ Not Working ${ }^{\mathrm{a}}$} \\
\hline Working & & & -.1400 & .8694 & -.1154 & .8910 & & & -2774 & .7578 & -.2555 & .7745 \\
\hline $\begin{array}{l}\text { Monthly Househ } \\
\text { Expenditure }\end{array}$ & & & -.0000 & 1.0000 & .0000 & 1.0000 & & & .0001 & 1.0001 & .0001 & 1.0001 \\
\hline $\begin{array}{l}\text { Number of Livin } \\
\text { Children }\end{array}$ & & & & & $-.0436^{*}$ & .9573 & & & & & -.0317 & .9688 \\
\hline $\begin{array}{l}\text { Number of } \\
\text { Sons who } \\
\text { have Died }\end{array}$ & & & & & -.0796 & .9235 & & & & & $-.2365 * *$ & .7894 \\
\hline-2 Log Likelihood & 1809.91 & & 1685.1398 & & 1685.14 & & 1590.3081 & & 1464.32 & & 1464.32 & \\
\hline $\begin{array}{l}\text { Model Chi } \\
\text { Squared }\end{array}$ & $34.71(8)$ & & $31.51(10)$ & & $38.11(12)$ & & $62.71(8)$ & & $60.02(10)$ & & $71.48(12)$ & \\
\hline $\begin{array}{l}\text { Use Correctly } \\
\text { Predicted }\end{array}$ & 81.57 & & 81.57 & & 81.57 & & 81.67 & & 81.56 & & 81.82 & \\
\hline Total N & 1894 & & 1763 & & 1763 & & 1669 & & 1535 & & 1535 & \\
\hline
\end{tabular}

Source: Original data file of PIHS 1995-96.

*Significant at .05 level.

**Significant at 01 level.

***Significant at .001 level.

${ }^{\text {a }}$ Reference category. 
Table 5

Logistic Regression Coefficients and Effects (Odd Ratios) of Selected Predictor Variables on Immunisation

\begin{tabular}{|c|c|c|c|c|c|c|c|c|c|c|c|c|}
\hline \multirow[b]{3}{*}{$\begin{array}{l}\text { Predictor } \\
\text { Variables }\end{array}$} & \multicolumn{6}{|c|}{ (a) Male Children 5 or Less Year of Age } & \multicolumn{6}{|c|}{ (b) Female Children 5 or Less Year of Age } \\
\hline & \multicolumn{2}{|c|}{ Model-1 } & \multicolumn{2}{|c|}{ Model-2 } & \multicolumn{2}{|c|}{ Model-3 } & \multicolumn{2}{|c|}{ Model-1 } & \multicolumn{2}{|c|}{ Model-2 } & \multicolumn{2}{|c|}{ Model-3 } \\
\hline & $\begin{array}{c}\text { Co- } \\
\text { efficients }\end{array}$ & $\begin{array}{c}\text { Odd } \\
\text { Ratios }\end{array}$ & $\begin{array}{c}\text { Co- } \\
\text { efficients }\end{array}$ & $\begin{array}{c}\text { Odd } \\
\text { Ratios }\end{array}$ & $\begin{array}{c}\text { Co- } \\
\text { efficients }\end{array}$ & $\begin{array}{c}\text { Odd } \\
\text { Ratios }\end{array}$ & $\begin{array}{c}\text { Co- } \\
\text { efficients }\end{array}$ & $\begin{array}{c}\text { Odd } \\
\text { Ratios }\end{array}$ & $\begin{array}{c}\text { Co- } \\
\text { efficients }\end{array}$ & $\begin{array}{c}\text { Odd } \\
\text { Ratios }\end{array}$ & $\begin{array}{c}\text { Co- } \\
\text { efficients }\end{array}$ & $\begin{array}{l}\text { Odd } \\
\text { Ratios }\end{array}$ \\
\hline Constant & .5583 & & .4321 & & .5264 & & .3872 & & .2763 & & .3891 & \\
\hline Age & .0673 & 1.0696 & .0725 & 1.0752 & .0785 & 1.0817 & $.1838^{* * *}$ & 1.2017 & $.1818^{* * *}$ & 1.1993 & $.1912^{* * *}$ & 1.2107 \\
\hline \multicolumn{13}{|l|}{ Residence } \\
\hline \multicolumn{13}{|l|}{ Rural $^{\mathrm{a}}$} \\
\hline Urban & .2695 & 1.3092 & .1444 & 1.1554 & .1445 & 1.1555 & $.4148^{*}$ & 1.5141 & $.3811^{*}$ & 1.4639 & $.4130^{*}$ & 1.5114 \\
\hline \multicolumn{13}{|l|}{ Province } \\
\hline \multicolumn{13}{|l|}{ Balochistan $^{\mathrm{a}}$} \\
\hline Punjab & .4344 & 1.5440 & .4880 & 1.6290 & .5731 & 1.7738 & 6099 & 1.8403 & $.7612 *$ & 2.1408 & $.8685^{* *}$ & 2.3834 \\
\hline Sindh & .5647 & 1.7589 & .6194 & 1.8579 & $.7354 *$ & 2.0863 & .1697 & 1.1850 & .3493 & 1.4181 & .5006 & 1.6498 \\
\hline NWFP & .3396 & 1.4044 & .2891 & 1.3352 & .4639 & 1.5903 & .2043 & 1.2267 & .2960 & 1.3444 & .4954 & 1.6412 \\
\hline \multicolumn{13}{|l|}{ Mother's Education } \\
\hline \multicolumn{13}{|l|}{ Uneducated $^{\mathrm{a}}$} \\
\hline Primary or Less & $.8296^{* *}$ & 2.2924 & $.7243 * *$ & 2.0634 & $.6742 *$ & 1.9624 & $.6109^{*}$ & 1.8421 & $.5654^{*}$ & 1.7602 & .4880 & 1.6291 \\
\hline Secondary or More & $1.0818^{* *}$ & 2.9499 & $.9213^{* *}$ & 2.5126 & $.8065^{*}$ & 2.2401 & $.9444 * *$ & 2.5714 & $.9285^{* *}$ & 2.5307 & $.8068^{*}$ & 2.2408 \\
\hline \multicolumn{13}{|l|}{ Family Type } \\
\hline \multicolumn{13}{|l|}{ Joint $^{\mathrm{a}}$} \\
\hline Nuclear & -.0092 & .9908 & .0551 & 1.0566 & .0350 & 1.0356 & -.1789 & .8362 & -.1209 & .8881 & -.1776 & .8372 \\
\hline
\end{tabular}


Table 5-(Continued)

\begin{tabular}{|c|c|c|c|c|c|c|c|c|c|c|c|c|}
\hline \multirow[b]{3}{*}{$\begin{array}{l}\text { Predictor } \\
\text { Variables }\end{array}$} & \multicolumn{6}{|c|}{ (a) Male Children 5 or Less Year of Age } & \multicolumn{6}{|c|}{ (b) Female Children 5 or Less Year of Age } \\
\hline & \multicolumn{2}{|c|}{ Model-1 } & \multicolumn{2}{|c|}{ Model-2 } & \multicolumn{2}{|c|}{ Model-3 } & \multicolumn{2}{|c|}{ Model-1 } & \multicolumn{2}{|c|}{ Model-2 } & \multicolumn{2}{|c|}{ Model-3 } \\
\hline & $\begin{array}{c}\text { Co- } \\
\text { efficients }\end{array}$ & $\begin{array}{c}\text { Odd } \\
\text { Ratios }\end{array}$ & $\begin{array}{c}\text { Co- } \\
\text { efficients }\end{array}$ & $\begin{array}{c}\text { Odd } \\
\text { Ratios }\end{array}$ & $\begin{array}{c}\text { Co- } \\
\text { efficients }\end{array}$ & $\begin{array}{c}\text { Odd } \\
\text { Ratios }\end{array}$ & $\begin{array}{c}\text { Co- } \\
\text { efficients }\end{array}$ & $\begin{array}{l}\text { Odd } \\
\text { Ratios }\end{array}$ & $\begin{array}{c}\text { Co- } \\
\text { efficients }\end{array}$ & $\begin{array}{l}\text { Odd } \\
\text { Ratios }\end{array}$ & $\begin{array}{c}\text { Co- } \\
\text { efficients }\end{array}$ & $\begin{array}{l}\text { Odd } \\
\text { Ratios }\end{array}$ \\
\hline \multicolumn{13}{|c|}{ Mother's Employment } \\
\hline \multicolumn{13}{|c|}{ Not Working ${ }^{\mathrm{a}}$} \\
\hline Working & & & $-.4101 *$ & .6636 & -.3751 & .6872 & & & -.3754 & .6870 & -.3639 & .6949 \\
\hline Monthly Househol & & & & & & & & & & & & \\
\hline Expenditure & & & $.0002^{*}$ & 1.0002 & $.0003^{* *}$ & 1.0003 & & & .0000 & 1.0000 & .0001 & 1.0001 \\
\hline $\begin{array}{l}\text { Number of Living } \\
\text { Children }\end{array}$ & & & & & -.0456 & .9554 & & & & & $-.0622 *$ & .9397 \\
\hline $\begin{array}{l}\text { Number of Sons } \\
\text { who have Died }\end{array}$ & & & & & -.1050 & .9003 & & & & & .0045 & 1.0045 \\
\hline$-2 \log$ Likelihood & 1146.005 & & 1087.292 & & 1087.292 & & 1006.254 & & 968.991 & & 968.991 & \\
\hline $\begin{array}{r}\text { Model Chi } \\
\text { Squared }\end{array}$ & $33.79(8)$ & & $42.22(10)$ & & $47.83(12)$ & & $45.14(8)$ & & $48.53(10)$ & & $54.15(12)$ & \\
\hline $\begin{array}{l}\text { Use Correctly } \\
\text { Predicted (\%) }\end{array}$ & 79.61 & & 79.85 & & 79.67 & & 80.02 & & 79.92 & & 80.12 & \\
\hline Total N & 1133 & & 1082 & & 1082 & & 1006 & & 966 & & 966 & \\
\hline
\end{tabular}

Source: Original data file of PIHS 1995-96.

*Significant at .05 level.

***Significant at 001 level.

${ }^{a}$ Reference category. 


\section{Age of Children}

The effect of children's age on health care utilisation in the equations, be it for both sexes or for male or female children only, is not significant [see Table 3(a) and Table 4 (a)(b)]. Interestingly, the direction of association is positive for male children and negative for female children. This implies that although age of children is not an important predictor of health care utilisation, yet the small variation it causes signifies that whereas health utilisation for sick children increases with the increase in the age of male children, the reverse is the case for female children who are relatively better taken care of when small.

As expected, the age of children has a positive and significant effect on the immunisation status of children [Table 3(b)]. A comparison of male and female children shows that although the direction of slope is positive for both male and female children, yet the relationship is significant for female children only [Table 5 (b)]. The addition of economic variables (Model-2) and demographic variables (Model-3) brings about negligible variation in the magnitude of coefficients, and the level of significance also does not change.

\section{Gender}

The results of the analysis (Table 3 ) show that the hypothesis mentioned at the beginning of the paper does not hold true. In other words, having a boy or a girl in a household does not make them privileged or underprivileged in the case of health care utilisation, be it curative or preventive medicine. The magnitude of the effect of this variable is not only negligible but also not significant. Hafeez (2001) analysing the data of two districts in the province of Punjab (Pakistan) also could not find any significant gender differentials in the provision of health care to the sick children. Similar were the findings of another earlier study based on simple cross-tabular analysis of the 1990-91 Pakistan Demographic and Health Survey data [Mahmood and Mahmood (1995)].

\section{Urban-rural Residence}

As indicated in Table 3, living in urban areas brings about a positive change in health care utilisation of sick children as compared to the ones living in rural areas. Nevertheless, the real benefit of living in urban areas, where access and proximity to health facilities are much better, goes to female sick children. Not only is the effect significant; the magnitude of the effect is also larger as compared to the male children (Table 4). Although the addition of economic and demographic variables has a depressive effect [B value decreases from .5138 in Table 4(b) Model-1 to .3729 in Table 4(b) Model-3] on health care utilisation of female children, yet living in urban areas remained an important factor as the effect remains significant. The preventive health care utilisation measured by the immunisation status of children 
also shows a positive and significant effect of living in urban areas for female children only, implying that girls living in urban areas are significantly more immunised as compared to those living in rural areas (see Table 5).

\section{Region of Residence}

In the province of Balochistan, which is sparsely populated and relatively underdeveloped, the accessibility and proximity of health care facilities is the lowest as compared to other provinces of Pakistan. This is also reflected in the fact that, in comparison, $\log$ odds of health care utilisation for children in the other three provinces increased substantially [see Table 3(a)]. Generally the increase in log odds becomes pronounced in almost all the provinces when economic and demographic variables are added to the variables in Model-1. A comparison by gender indicates that the effect is generally higher for female than male children [Table 4(a)(b)]. That is true at least for the provinces of Punjab and Sindh. As expected, the province of Punjab, being relatively more developed, has shown the highest magnitude of coefficients of health care utilisation for both male and female children. The province of Sindh follows the province of Punjab in predicting health care utilisation. The effect is also significant at .001 level in both the provinces.

Just like the equation on health care utilisation, the coefficient and the odds ratios in the case of equations on immunisation status of children also increase when economic and demographic variables are added to the controlling variables equation, i.e., Model-1. However, predictive value is not as strong as it is in the case of health care utilisation (see Table 3).

Nevertheless, by looking at the gender differences in these provinces (Table 5), it is found that the predictive value of the province of Punjab is stronger in the equation based on female children. But the province of Sindh shows stronger predictive value in the equation on male children. In other words, whereas girls are more likely to be immunised in the province of Punjab, boys are more likely to be immunised in the province of Sindh.

\section{Mother's Education}

The "mother's education" has been established as one of the strongest and important predictors of socioeconomic and demographic behaviour in Pakistan [Ali (1999); Ali (2000); Ali, Siyal and Sultan (1993)]. However, in the analysis of health care utilisation of sick children, its effect is not significant [Table 3(a)]. In other words, a mother's educational attainment does not inculcate a discriminatory attitude in the provision of health care to her sick children [see Table 4(a)(b)].

On the other hand, a "mother's education" brings about a positive change in the immunisation status of children. Generally, although the magnitude of effect denoted by $\mathrm{B}$ values decreases with the introduction of economic and demographic 
variables in the equation, yet the effect remains statistically significant [Table 3(b)]. More often, the magnitude of effect of a mother's education upto primary or lower classes is relatively greater for male than for female children, and the effect remains significant for at least male children. Interestingly, secondary or higher education among mothers in the equations (Table 5, Model-3) brings about a similar magnitude of effect for both male and female children, implying that it is secondary or higher level of education which brings rationality to mother's attitude, and hence mothers get their children immunised irrespective of the sex of their children.

\section{Family Type}

Living in a nuclear family shows a clear disadvantage for both male and female sick children, as they are less likely to have been utilising health facilities than the ones living in joint families. However, the family-type divide has not affected significantly the immunisation status of children. It may be because of the fact that in early and mid-90s, the Expanded Programme of Immunisation (EPI) was a top priority of the government and immunisation teams were inoculating children at their doorstep. The pattern shown above for health care utilisation and the immunisation status of children is followed in equations classified by male and female children. In view of the magnitude of coefficients, female children are certainly in a more disadvantageous position, be it for health care utilisation or the immunisation status of children.

As noted already, sons are valued more in Pakistan. The importance of sons is enhanced in joint families where grandparents are also residing. In case of children's illness, it is the grandparents who are more concerned about the well-being of their grandsons. It is a natural feeling, for survival of their grandsons is important to them for familial lineage, and also for economic and social security.

\section{Mother's Employment}

As expected, mother's employment has a negative impact on both the health care utilisation and immunisation status of children (Table 3). Nevertheless, in the case of equations on immunisation of children, the negative impact is not only large, it is statistically significant too. This implies that mother's labour force participation has a worsening impact on the immunisation status of children, as such children are less likely to receive immunisation shots and drops against diseases.

Although for a mother the most precious thing is her children but a working mother in Pakistani society is the busiest person. She is not only devoting time to work that is gainful, she is also busy with household chores, which normally include cooking food, cleaning and upkeep of the house, washing clothes, and providing services to every member of the household including the husband. In this situation, her children are the ones who suffer the most. A comparison of male and female 
equations shows that the negative impact of mother's labour force participation on health care utilisation is relatively larger on female than male children. However, the impact is not statistically significant; whereas, on immunisation status, the negative impact is reduced more in the case of male children when demographic variables are added to the equation. Consequently, the statistically significant impact of mother's employment becomes not significant.

\section{Monthly Household Expenditure}

Contrary to expectation, 'monthly household expenditure' does not bring about any variation in 'health care utilisation' of either male or female sick children. The magnitude of coefficient remains almost identical in all the six equations [Table 3(a), 4(a) (b), Models-2 and 3]. But for immunisation status, the importance of this variable cannot be compromised at least for male children as it turns out to be statistically significant [Table 5(a), Models 2 and 3]. This significance level was achieved in spite of very low magnitude of the coefficient.

\section{Number of Living Children}

The number of living children does explain some variation in the equations on health care utilisation as well as the immunisation status of children. The negative impact is also statistically significant [Tables 3(a) and (b)]. The analysis by sex of the children shows that whereas in the equations on 'health care utilisation' the impact is significant for male children only, on immunisation status, a statistically significant impact is found for female children only (Tables 4 and 5). This significance level is achieved in spite of the fact that the magnitude of the coefficient was not large, implying that the variable is important in spite of the fact that its predictive power is low.

\section{Number of Sons Who Have Died}

It is conjectured that where there are more deaths of sons, parents would be more sensitive to the sickness of their children, in particular their sons, and hence would leave no stone unturned to provide health care, be it curative or preventive.

Contrary to expectation, every additional death of a son controlling for other predictor variables decreases the log odds of 'health care utilisation' by .0796 for male children and by .2365 for female children [Tables 4 (a) (b), Model 3]. The impact for female children is also significant at 99 percent confidence interval. Nevertheless, it may be noted that although gender differentials are small, yet male children are slightly better taken care of when sick as compared to female children. This variable has negligible impact on the immunisation status of children, be they male or female. 


\section{SUMMARY AND CONCLUSIONS}

The World Bank (1994) report reveals that in 17 of the 29 developing countries, including Pakistan, female children of 1-4 years of age were found to have higher mortality rates than male children. In many of these countries, the underlying cause of high mortality among girls is reported to be parents' bias against girls in providing health care when they are ill. Pakistan is labelled as one of the countries where gender bias against females is conjectured to be existing in every walk of life including health care utilisation. The purpose of our study, therefore, was to test whether or not gender bias existed in health care utilisation of sick children in Pakistan.

Overall, the results are encouraging, as medical consultation has been sought for a very high proportion (79 percent) of sick children. Moreover, there do not appear to be significant differences by gender in health care utilisation, be it curative or preventive. However, the extent and magnitude of the effect varies by geographical, socio-economic, and demographic characteristics of the mothers. For example, as compared to rural areas, female children residing in urban areas availed of significantly more curative and preventive health care facilities. Moreover, as compared to the province of Balochistan, the log odds in the provinces of Punjab and Sindh are also substantially higher for females in the equation on health care utilisation for curative purposes, implying a preferential attitude of parents towards daughters in these provinces. Likewise, girls are also more likely to be immunised in Punjab, whereas boys are more likely to be immunised in Sindh.

Mother's education beyond primary level brings about almost identical but positive and significant change in the immunisation status of both male and female children. On the other hand, in the provision of health care services to sick children, mothers with the same level of education do show some gender differentials although the impact for both male and female children is not significant. In the nuclear family set-up, females as compared to male sick children are relatively in a more disadvantageous position in the provision of health care facilities. The negative impact of mother's employment on health care utilisation is also greater for female sick children. However, in spite of the fact that monthly household expenditure brings almost no change in the log odds across various equations, be they on immunisation status or on health care utilisation of sick children, it turns out to be an important variable for the immunisation status of children, in particular for male children. The number of living children a woman has brings about a negative and significant impact on health care utilisation of male children; whereas on the equations of immunisation status, a similar negative impact is had for female children only. The number of dead sons also brings about a relatively larger negative impact on female than male sick children in the equations on health care utilisation. 
Contrary to the general observations and expectations, the results of this study, as mentioned earlier, suggest that on the whole there do not appear to be any gender differentials in the provision of health care. This is so in spite of the fact that many studies in Pakistan on various gender-related issues have shown significant gender bias in favour of male children [Mahmood and Nayab (1998); Sathar and Kazi (1997); Ali (1989)]. Thus, one may conclude that parental altruism prevails at least in the provision of health care to sick children.

In Pakistan, household duties are divided in such a way that all work inside the house is performed by housewives whereas, normally, outside duties are performed by husbands. It is also observed that among Pakistani families, in general, the father is relatively more affectionate to his daughters, and sons are dearer to the mother. Since medical consultation and treatment for sick children is normally sought by fathers, love and similar feelings of a father towards his sick daughters counterbalance the socio-cultural bias in favour of boys and hence sick daughters are equally taken care of at least in the provision of health care.

Nevertheless, efforts should be made to minimise gender differentials among various categories of people so that children living in every circumstance may have equal opportunity of health care utilisation. This will be possible when mothers in general are empowered with the ability of decisions-making, and provided with greater access to household resources and autonomy. In both Kerala, India, and Sri Lanka, mothers have a lot of independence and thus provision of treatment to sick children is almost entirely the concern of a mother [Sushama (1990)]. Moreover, to minimise these differentials, health care facilities should be made easily and universally available to all. The 'Lady Health Workers' programme of the Government of Pakistan is a major positive step in this regard. Under this programme, health care facilities are provided at people's doorstep. The expansion of this programme will be extremely beneficial in helping parents to provide health care facilities to children, be they male or female.

\section{REFERENCES}

Ahmed, Ambareen (1990) Gender Differentials in Access to Health Care for Pakistani Children. Study Conducted for UNICEF, Pakistan.

Ahmed, Tauseef, M. H. Bhatti, and G. Bicego (1992) Infant and Child Mortality. Chapter 9 in Pakistan Demographic and Health Survey 1990-91, NIPS/IRD/Macro International Inc. Islamabad, Pakistan/Colombia, Maryland, USA.

Ali, S. Mubashir (2000) Culture Poverty and Child Survival. Pakistan's Population Issues in the 21st Century. Conference Proceeding Oct. 24-26. Karachi: Population Association of Pakistan. 485-494. 
Ali, S. Mubashir, H. B. Siyal, and Mehboob Sultan (1993) How Similar are the Determinants of Fertility and Mortality? The Pakistan Development Review 32: 4 $1107-1115$.

Ali, S. Mubashir (1989) Determinants of Family Size Preferences in Pakistan. The Pakistan Development Review 28:3 207-232.

Ali, S. Mubashir, and Mahboob Sultan (1999) Socio-cultural Constraints and Women's Decision Making Power Regarding Reproductive Behaviour. The Pakistan Development Review 38:4 689-696.

Booth, B., and M. Verma (1992) Decreased Access to Medical Care for Girls in Punjab, India: The Roles of Age, Religion, and Distance. American Journal of Public Health 82:2 1155-1157.

Cleland, J., A. Hakim, and M. N. I. Farooqui (1998) Health and Survival. Chapter 8 in Pakistan Fertility and Family Planning Survey 1996-97. NIPS/London School of Hygiene and Tropical Medicine.

Gupta, M. Das (1987) Selective Discrimination Against Female Children in Rural Punjab, India. Population and Development Review 13: 177-100.

Hafeez, Mohammad (2001) Gender and Other Differences in Health: Findings from Urban and Rural Sites in Lahore and Bahawalnagar, Pakistan. PhD Thesis Canberra, ACT: Australian National University.

Mahmood, N., and Dure Nayab (1998) Gender Dimensions of Demographic Change. The Pakistan Development Review 37:4 705-725.

Mahmood, N., and M. A. Mahmood (1995) Gender Difference in Child Health Care Practice: Evidence from the Pakistan Demographic and Health Survey. The Pakistan Development Review 34:4 693-707.

MHDC (1999) Human Development in South Asia 1999. Islamabad: The Mahbub Ul Haq Human Development Centre.

Pakistan Medical Research Council (1998) National Health Survey of PakistanHealth Profile of the People of Pakistan. Islamabad: Pakistan Medical Research Council.

Pakistan, Government of (1997) Pakistan Integrated Household Survey -1995-96 Islamabad: Statistics Division.

Pakistan, Government of (1998) Population and Housing Census 1998. Islamabad: Population Census Organisation.

Qureshi, S. K., and G. M. Arif (1999) Profile of Poverty in Pakistan 1998-99. Mimeographed Paper. Pakistan Institute of Development Economics, Islamabad.

Sathar, Zeba A., and Shahnaz Kazi (1997) Women's Autonomy, Livelihood and Fertility: A Study of Rural Punjab. Islamabad: Pakistan Institute of Development Economics.

Sushama, P. N. (1990) Social Context of Health Behaviour in Kerala. In John C. Caldwell et al. (eds) What we Know about Health Transition: The Cultural, Social and Behavioural Determinants of Health. Health Transition Centre. Canberra: The Australian National University. 777-787. 
United Nation Development Programme (1996) Human Development Report. New York: United Nation Development Programme.

Williamson, J. B., and V. Boehmer (1997) Female Life Expectancy, Gender Stratification, Health Status and Level of Economic Development: A Crossnational Study of Less Developed Countries. Social Science and Medicine 45:2 305-317.

World Bank (1994) A New Agenda for Women Health and Nutrition Despite Girls Biological Advantage. Washington, D. C.: World Bank. 